\title{
METALLIC COMPOUNDS IN THE PHASE OF THE RETICULATED IONIC POLYMERS
}

\author{
Vasile Gutsanu $^{\text {a* }}$, Constantin Turta ${ }^{\mathrm{b}}$, George Filotic \\ ${ }^{a}$ Department of inorganic and physical Chemistry, State University of Moldova, \\ 60 A.Mateevich str., MD-2009 Chisinau, Moldova *Email: gutsanu@gmail.com \\ ${ }^{b}$ Institute of Chemistry, Academy of Sciences of Republic of Moldova, \\ 3, Academiei str.. MD-2028, Chisinau, Moldova \\ ' National Institute of Materials Physics, Atomistilor str.105 bis, \\ PO Box MG.7, Magurele, Bucharest, Romania, 077125
}

\begin{abstract}
In this review there are described the results of studying of iron ions state in the ion-exchange resins (KU2, AN-31, AV-17, Varian - AD, EDE-10P), obtained by Mossbauer spectroscopy. The iron ions have been sorbet on ion exchangers, from aqueous solutions at different temperatures and air conditions. The iron state in polymer phase depends of nature of electron donor groups - amine or carboxylic. To explain the form and temperature dependence of Mossbauer spectra of polymer phase containing iron it was proposed the presence of different compounds like $\beta$-FeOOH, $\alpha-\mathrm{Fe}_{2} \mathrm{O}_{3}$, and jarosite mineral type compounds: $\left(\mathrm{R}_{4} \mathrm{~N}_{2} \mathrm{H}_{3} \mathrm{O}\right)\left[\mathrm{Fe}_{3}(\mathrm{OH})_{6}\left(\mathrm{SO}_{4}\right)_{2}\right]$ or coordination modes: $\left\{\mathrm{RCOO}-\mathrm{Fe}\left(\mathrm{L}_{4}\right)-\mathrm{OOCR}\right\}^{1+},\left\{\mathrm{R}-\mathrm{CO}_{2}=\mathrm{Fe}\left(\mathrm{X}_{2}\right)=\mathrm{O}_{2} \mathrm{C}-\mathrm{R}\right\} \mathrm{n},\left\{\mathrm{R}-\mathrm{COO}-\mathrm{Fe}\left(\mathrm{X}_{4}\right)-\mathrm{OOC}-\mathrm{R}\right\} \mathrm{n}$, and $\left\{(-\mathrm{NCH} 2 \mathrm{CH} 2 \mathrm{~N}-)=\mathrm{Fe}\left(\mathrm{X}_{2}\right)\right.$ $\left.=\left(-\mathrm{NCH}_{2} \mathrm{CH}_{2} \mathrm{~N}-\right)\right\}$, where $\mathrm{X}=\mathrm{H}_{2} \mathrm{O}, \mathrm{OH}-, \mathrm{SO}_{4}{ }^{2-} ., \mathrm{n}=$ from 3 - to $1+$. In special conditions the ultrafine superparamagnetic particles of $\mathrm{Fe}_{2} \mathrm{O}_{3}$ have been obtained.
\end{abstract}

Keywords: ion exchangers, Mossbauer spectra, iron, superparamagnetic, complexes, polymer phase.

\section{Introduction}

Reticulated ionic polymers produced in large amounts by chemical industry are widely used as ion exchangers in the water treatment of thermal and nuclear electric power plants, in waste-water and gas purification, in separation and concentration of substances, as well as in acid-basic catalysis. The ion exchange process is conditioned by electrostatic Coulomb interactions between atoms with definite electrical charges located in the polymer matrix and mobile ions (contrioni). Therefore, this process is virtually no selective in retention of micro-molecular ions.

In many cases the ion exchange is accompanied by other secondary, often uncontrolled, processes that affect polymers during their use. The ion exchangers are frequently poisoned by iron compounds, which results in reduction their service life and involve considerable additional expenses on chemical reagents and water for their regeneration [13]. Often the processes of the ion exchangers "poisoning" are irreversible [3]. All types of ion exchangers are "poisoned" by iron compounds. Poisoning via iron compounds presence can occur even during exchangers" production [4] by acids or bases solutions, not enough pure [5].

Reticulated ionic polymers containing electron donor atoms (amino groups, phenolic, carboxylic, etc..) can simultaneously participate to complexing mechanisms besides ion exchange process, too. Complexing metal cations by poly-ligands is a relatively new direction in the chemistry active polymers [6.7].. The synthesis of metal compounds in the form of ultrafine particles in the polymer phase is considered to be a new direction in physical chemistry of chemically active polymers [8,9]. Polymers loaded with metallic compounds significantly change their physico-chemical properties. They can become catalysts [10], selective sorbents [11-14], biochemical models of transport substances [15] as well as models for experimental research of relaxation processes [16]. In order to use the metal containing polymers in different physical or chemical processes - it is necessary to know and to control the conditions of loading these metal compounds and, especially to induce the right metal cation state in the polymer phase. Knowing exactly the ions' state in polymer phase is quite difficult for several reasons. Firstly, the polymers of this class are amorphous and reticulated, which limits the number of suitable investigation methods. Secondly, the loading processes of reticulate ionic polymers with metal compounds gives simultaneously rise to other concurrent processes, and an ion exchange is generally required.

These processes depend on several factors such as nature and concentration of electrolyte, temperature, $\mathrm{pH}$ of the solution, contact time with the polymer solution. The processes evolve either in static or in dynamic conditions, while the presence of air in the system, nature and concentration of organic solvent, could directly or indirectly influence the processes of formation of metal compounds inside the polymer. The best methods of studying metal and non-metal ions parameters and properties in the reticulated polymer phase are the Mossbauer spectroscopy, ESR, IR, and magnetic measurements. 


\section{Results and Discussion}

\section{State of ions in the ionic reticulated polymer phase containing carboxylic groups}

As a results of the investigations using potentiometric method and IR spectroscopy [17] it is known that in carboxylic polymer SG-1 type at contact with a solution of 0.003 $0.5 \mathrm{M} \mathrm{Fe}\left(\mathrm{NO}_{3}\right)_{3} 3$ in $0.5 \mathrm{M} \mathrm{NaNO}$ in a pH range 1-2.5 the complexes of the typeare formed.

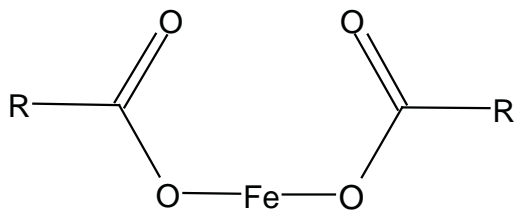

They are stable in the $\mathrm{pH}$ range $2.5 \sim 5.0$. These complexes decompose in solutions with $\mathrm{pH}>7$ and $\gamma$-FeOOH phase is formed. According to [18], a Fe ${ }^{3+}$ ions from the solution of $\mathrm{FeCl}_{3}$ are retained by the $\mathrm{KB}-4$ polymer as a result of complexing process via carboxylic groups with final formation of a precipitate.

The presence of solvent in the polymer phase leads to increasing of $\mathrm{Fe}^{3+}$ ions oscillation amplitude and electric field gradient $(\mathrm{EFG})$ on their nucleus. The solvent $\left(\mathrm{H}_{2} \mathrm{O}\right)$, which molecules coordinate to metal ions, primarily affects the ion oscillations in chemical bond with ligand, as well as the oscillation of the polymer chain. The non-polar solvent influences primarily, on chain oscillation. Various measurements [19] show that the Mossbauer spectra (MS) of Fe ${ }^{3+}$ ions in carboxylic polymer phase (КБ-2 and others) exhibit doublet patterns. The observed differences, often essential, of iron ions state in carboxylic polymer phase [18-20] confirm that it depends on many factors, which are not always taken into account.

It is surprising that the nature of anions $\left(\mathrm{Cl}^{-}, \mathrm{SO}_{4}^{2-}\right)$ influence $\mathrm{Fe}^{3+}$ cations complexation with carboxylic groups of cationite. Increasing of the concentration of either $\mathrm{Cl}^{-}$or $\mathrm{SO}_{4}{ }^{2}$-anions have induced a diametrically opposite influence on the sorption of $\mathrm{Fe}^{3+}$ ions by KB-2 cationite [21].

Sorption of $\mathrm{Fe}(\mathrm{II})$ from tartaric acid solutions $(0.005 \mathrm{~N}$ of Mohr salt, $10 \mathrm{mmol} / \mathrm{L}$ of tartaric acid) by $\mathrm{KB}-2$ polymer occurs in the $\mathrm{pH}$ range 3-9 with a maximum at $\mathrm{pH}$ 6.5. In the polymer phase almost all $\mathrm{Fe}^{2+}$ ions being oxidized up to $\mathrm{Fe}^{3+}[22]$.

The $\mathrm{Fe}^{2+}$ and $\mathrm{Fe}^{3+}$ ions in cationite $\mathrm{KB}-2$ phase retained from solutions of $0.005 \mathrm{~N}^{57} \mathrm{Fe}_{2}\left(\mathrm{SO}_{4}\right)_{3}(\mathrm{pH} 2), \mathrm{FeSO}_{4}$ (inert gas atmosphere, $\mathrm{pH}=5),\left(\mathrm{NH}_{4}\right)_{2} \mathrm{Fe}\left(\mathrm{SO}_{4}\right)_{2}$ in $0,01 \mathrm{M}$ tartaric acid $(\mathrm{pH} 5)$ are found in the high-spin state and in octahedral environment [19]. By keeping in air atmosphere, the oxidation of $\mathrm{Fe}^{2+}$ ions in the KB-2 polymer phase ends up to $\mathrm{Fe}^{3+}$ is occurred. But the state of oxidized ions differs from the state of $\mathrm{Fe}^{3+}$ ions absorbed from the $\mathrm{Fe}_{2}$ $\left(\mathrm{SO}_{4}\right)_{3}$ solution as described in the followings. The $\mathrm{Fe}^{2+}$ ions retained from $\mathrm{FeSO}_{4}$ solutions are complete oxidized, and those retained from $\left(\mathrm{NH}_{4}\right)_{2} \mathrm{Fe}\left(\mathrm{SO}_{4}\right)_{2}$ solutions are only partially oxidized. Existence of tartaric acid in the system from where the $\mathrm{Fe}^{2+}$ ions were detained from contributes to their oxidation during the storage of polymer in the air [19]. Asymmetrical lines in Mossbauer spectra of KB-2 samples, containing $\mathrm{Fe}^{3+}$ obtained as a result of air oxidation of $\mathrm{Fe}^{2+}$ ions, may be as the results that some $\mathrm{Fe}^{3+}$ ions are in the form of precipitate and need supplemental investigation. Although the presence of $\mathrm{Cl}^{-}$and $\mathrm{SO}_{4}^{2-}$ anions influence in different mode on $\mathrm{Fe}^{3+}$ sorption by $\mathrm{KB}-2$, the stabilized state of $\mathrm{Fe}^{3+}$ ions practically does not depend on the nature of anions in polymer phase. It is assumed that in polymer phase one part of $\mathrm{Fe}^{3+}$ ions is in the form of $\gamma-\mathrm{FeOOH}$. $\mathrm{Fe}^{3+}$ ions from the $\mathrm{Fe}_{2}\left(\mathrm{SO}_{4}\right)_{3}$ solution with $\mathrm{pH} 1.2$ are retained by the KB-2 polymer due to of their complexation with carboxylic groups only. The parameters of Mossbauer spectra of KB-2 samples retained $\mathrm{Fe}^{3+}$ ions from solution with $\mathrm{pH} 1.2$ differ for relevancy from those who have retained cations from solution with $\mathrm{pH} 1.7$ - 2.0 [19]. The effected investigations using IR spectroscopy [19] showed that the retention of $\mathrm{Fe}^{3+}$ cations from $\mathrm{Fe}_{2}\left(\mathrm{SO}_{4}\right)_{3}$ solutions the complexes of type I are formed in polymer $\mathrm{KB}-2$ phase, but from $\mathrm{FeCl}_{3}$ solutions - complexes of type I and II co-exist.

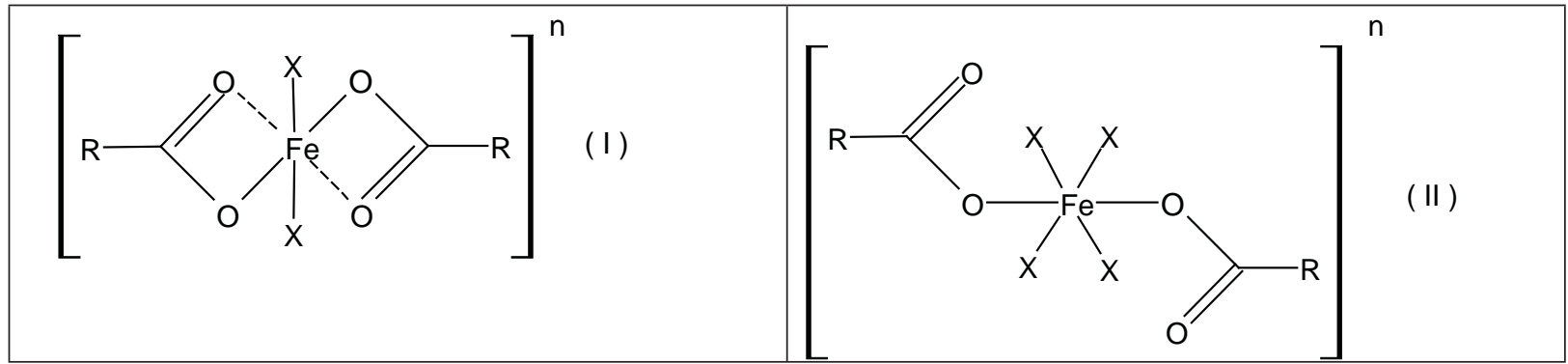

where $\mathrm{X}$ may be $\mathrm{H}_{2} \mathrm{O}, \mathrm{OH}-, \mathrm{Cl-}, \mathrm{SO}_{4}^{2-}$, and $\mathrm{n}$ may has the values from $1+$ to $3^{-}$. 


\section{State of iron ions in the phase of the anion exchangers containing amine groups}

Anion exchangers containing amine groups, are able to retain both hidroxycationes $\mathrm{of} \mathrm{Fe}^{2+}$ and $\mathrm{Fe}^{3+}$ [21], as well as their complexes from the solutions containing tartaric acid [22.23]. Opportunity to observe Mössbauer spectra at $300 \mathrm{~K}$ of a wet sample anion exchanger EDE-10P demonstrates unequivocally coordination of ions with amine groups of polymer [24]. The parameters of Mössbauer spectra $(\delta \mathrm{Na}+=0.62-0.72 \mathrm{~mm} / \mathrm{s}, \Delta \mathrm{EQ}=0.72-0.79 \mathrm{~mm} / \mathrm{s}(\delta \mathrm{Na}+$ - isomer shift relative to sodium nitroprusside as reference substance, $\Delta \mathrm{E}_{\mathrm{O}}$ - quadrupol splitting) shows that $\mathrm{Fe} 3+$ ions in polymer phase is in a high-spin state and having a somewhat perceptible distorted octahedral environment.

Relatively small values of spectral lines width $\Gamma=0.52-0.56 \mathrm{~mm} / \mathrm{s}$ and no diffuse broadening of spectra with increasing temperature, especially at $\mathrm{T}>\mathrm{T}_{\text {melting }}$ of ice, also confirms that $\mathrm{Fe}^{3+}$ ions in the EDE-10P polymer phase are coordinated with electron donor atoms of poly-ligand matrix. According to the composition of polymer structural unit [4] and the results of publications [24.25] it may be considered that $\mathrm{Fe}^{3+}$ ions form compounds of bis-ethylenediamine type in the anion exchanger EDE-10P phase.

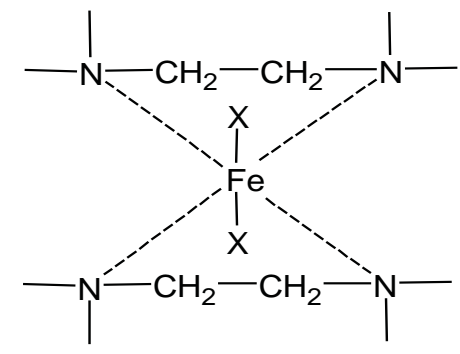

At the retention of iron ions in the anion exchanger AN-2FN phase, containing phenolic groups, secondary and tertiary amines [4.26], from the solution of $\mathrm{Fe}_{2}\left(\mathrm{SO}_{4}\right)_{3}, \mathrm{Fe}^{2+}$ ions were also detected in the polymer phase, too [27]. The $\mathrm{Fe}^{2+}$ and $\mathrm{Fe}^{3+}$ ions are in a high-spin state from AN-2 $\mathrm{FN}$ polymer phase (Table 1).

The Mossbauer spectra parameters $( \pm 0.04 \mathrm{~mm} / \mathrm{s})$ of plymer AN-2FN

Table 1 after contacting with $\mathrm{Fe}_{2}\left(\mathrm{SO}_{4}\right)_{3}$ solution at different temperatures.

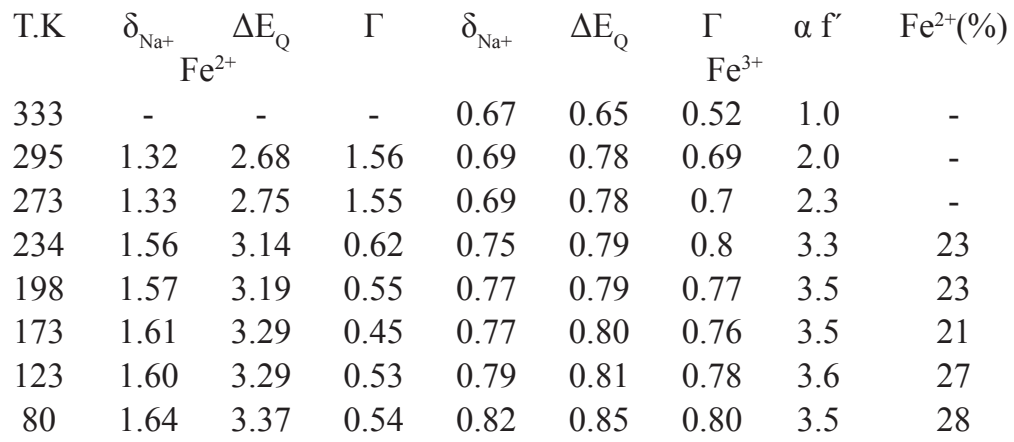

Note: $\alpha \mathrm{f}^{\prime}$ - a prportional value of Mossbauer effect probability $\left(\mathrm{f}^{\prime}\right)$ for integral spectrum.

For $\mathrm{Fe}^{2+}$ (Tab.1) ions the sharp and essential increasing of line width $(\Gamma)$ at $\mathrm{T}>273 \mathrm{~K}$ is related to diffusion of these ions to the active centers of polymer.

The shape of Mössbauer spectra and their evolution with temperature (Fig. 1), seems at the first glimps to correspond to mixed valence iron complexes $\left(\mathrm{Fe}^{2,5+}\right)$. However a thorough analysis of the results does not confirm this assumption. The sharp diminution of the Mössbauer effect probability for $\mathrm{Fe}^{2+}$ at $\mathrm{T}>273 \mathrm{~K}$ is probably determined by increasing of amplitude of oscillation of the polymer chain (scheme A) affecting the Debye temperature of the whole entity. The $\mathrm{Fe}^{3+}$ cations form compounds with a reduced occurrence of chain oscillation (Scheme B) in the polymer. 


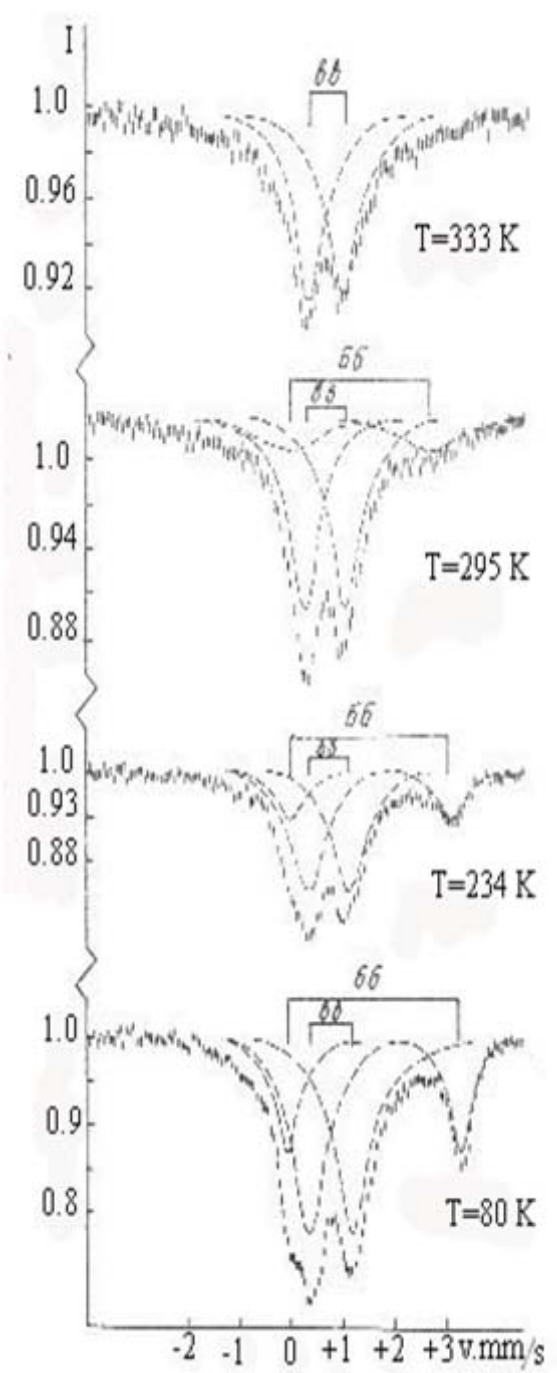

Fig. 1. The Mossbauer spectra of polymer AN2FN retaiting the iron ions from the solution of $\mathrm{Fe}_{2}\left(\mathrm{SO}_{4}\right)_{3}$ at different temperatures.
At treating of polymer sample by $3 \% \mathrm{H}_{2} \mathrm{O}_{2}$ solution a part of $\mathrm{Fe}^{3+}$ ions is reduced up to $\mathrm{Fe}^{2+}$. In this case the Mössbauer effect fraction is not zero at $300 \mathrm{~K}$. So, the vibration amplitude of $\mathrm{Fe}^{2+}$ in the coordinative node $\mathrm{B}$ is lower than in A, i.e strongest bonded in composite lattice.
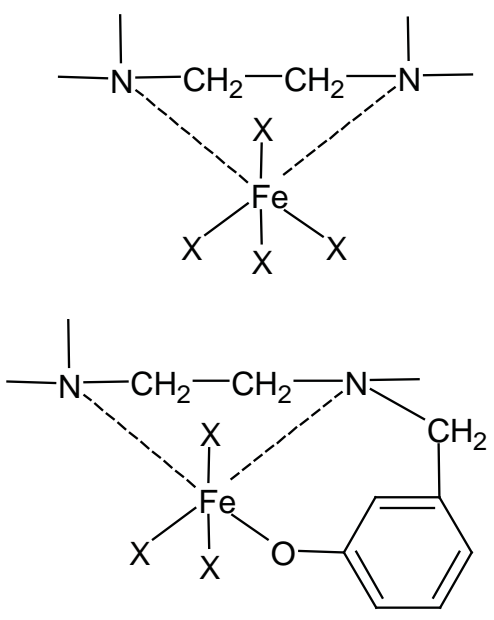

where $\mathrm{X}$ may be $\mathrm{H}_{2} \mathrm{O}, \mathrm{OH}^{-}, \mathrm{SO}_{4}^{2-}$.

Putting in contact a water - acetone solution and the sample of polymer EDE-10P, which contains $\mathrm{Fe}^{3+}$ from solution of $\mathrm{FeCl}_{3}$, the Mossbauer spectra parameters $\delta_{\mathrm{Na}+}$ and $\Delta \mathrm{E}_{\mathrm{Q}}$ have constant values both at 80 as well as $300 \mathrm{~K}$ [24], in the whole range of concentration of acetone from 0 to $100 \%$. When dealing with the EDE-10P sample and water - ethanol solution the $\Delta \mathrm{E}_{\mathrm{Q}}$ value remains virtually constant throughout the all range of concentrations of ethanol, but the $\delta_{\mathrm{Na}^{+}}$value is noticeable changed, especially at $\sim 10-15 \%$ of ethanol [24].

Perhaps this change in $\delta_{\mathrm{Na}+}$ value at this peculiar concentration of ethanol, is determined by the change of the solution structure [28.29]. The Mossbauer fraction data $\mathrm{f}^{\prime}{ }_{300} /$

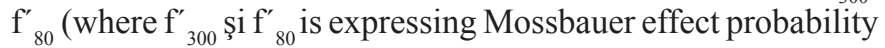
at 300 and $80 \mathrm{~K}$ respectively) indicate that with increasing the acetone concentration and, especially, the ethanol ones in their solution with water the vibration amplitude of $\mathrm{Fe}^{3+}$ ions is decreased [24]. Enhancing the organic component concentration in solution gives rise to augmentation of the relaxation time, which, considering the low iron content in the polymer phase $(15 \mathrm{mg} / \mathrm{g})$, it seems to be most probably of spinlattice type. This rezoning is confirmed by comparing $\Gamma_{80 \mathrm{~K}}=0.57 \mathrm{~mm} / \mathrm{s}$ and $\Gamma_{300 \mathrm{~K}}=0.40 \mathrm{~mm} / \mathrm{s}$ for EDE-10P probe containing $\mathrm{Fe}^{3+}$ after its treatment with $100 \%$ acetone.

The experimental data show that the nature and concentration of anions in solution influence on $\mathrm{Fe}^{3+}$ ions sorption by anion exchangers containing weak basic groups [21.30]. Taking into account the high concentration of anions in the anion exchangers phase (up to 5-8 M) one may assume that some anions coordinate to $\mathrm{Fe}^{3+}$ ions bounded with groups-ligands of polymer. But the performed investigations using Mossbauer spectroscopy [31] did not provide clear detection of any influence of anions $\mathrm{ClO}_{4}^{-}, \mathrm{NO}_{3}^{-}, \mathrm{Cl}^{-}, \mathrm{SO}_{4}^{2-}$ on electronic state of $\mathrm{Fe}^{3+}$ ions retained by the polymer EDE-10P. This fact does not exclude anions coordination to Fe3+ ions in the anion exchanger comprising weak basic groups. The state of $\mathrm{Fe}^{3+}$ ions in the EDE-0P polymer phase is determined by ethylenediamine groups and presence of water molecules or $\mathrm{OH}^{-}$ions in solution and practically doesn't change it. A similar trend for $\delta_{\mathrm{Na}^{+}}$values was observed for the addition of ethylenediamine to solutions of $\mathrm{Sn}(\mathrm{IV})$ halides [32].

Anions possessing red-ox or complexion character could change essentially the state of iron ions in the anion exchanger phase. When processing with $\mathrm{Na}_{2} \mathrm{~S}$ solution the majority of $\mathrm{Fe}^{3+}$ cations from the EDE-10P polymer phase to $\mathrm{Fe}^{2+}$ [33]. Reduction of $\mathrm{Fe}^{3+}$ ion the complexes with EDE-10P poly-ligand is blocked when FeS is formed. The FeS compounds appears as ultra fine particles which freely diffuse into the liquid phase of polymer and at $\mathrm{T}>\mathrm{T}_{\text {melt }}$ of ice, $\mathrm{f}^{\prime}=$ 0 . After prolonged exposure to air a part of $\mathrm{Fe}^{2+}$ ions are again oxidized to $\mathrm{Fe}^{3+}$. If one assume that the parameter $\mathrm{f}^{\prime}$ has the same value in the initial wet sample, for $\mathrm{Fe}^{2+}$ and $\mathrm{Fe}^{3+}$ at $80 \mathrm{~K}$, then the $\mathrm{Fe}^{2+}$ ions are $74 \%$ and $\mathrm{Fe}^{3+}-26 \%$. $\mathrm{Checking}^{3}$ 
sample storage in air after 6 days, 1 and 6 months the amount of $\mathrm{Fe}^{2+}$ is continuously decreased to $62,55.5$ and $46 \%$, respectively.

In the polymer phase during the storage of a sample in air the processes (1) - (3)

$$
\begin{gathered}
2\left[\left(\mathrm{R}_{3} \mathrm{~N}\right) \mathrm{nFe}\right]^{3+}+3 \mathrm{~S}^{2-}=2 \mathrm{FeS}+\mathrm{S}+2 \mathrm{n} \mathrm{R} \mathrm{R} .(1) \\
4 \mathrm{FeS}+3 \mathrm{O}_{2}+2 \mathrm{H}_{2} \mathrm{O}=4 \mathrm{FeOOH}+4 \mathrm{~S} \\
2 \mathrm{FeOOH}+3 \mathrm{H}_{2} \mathrm{~S}=2 \mathrm{FeS}+4 \mathrm{H}_{2} \mathrm{O}+\mathrm{S}(3)
\end{gathered}
$$

take place analogous to those described in [35]:

Depositing in air the EDE-10P sample processed with $\mathrm{Na}_{2} \mathrm{~S}$ solution the increase of particle size and modification of structure of compounds containing iron has involved a change the Mossbauer parameters $\delta_{\mathrm{Na}+}, \Delta \mathrm{E}_{\mathrm{Q}}, \Gamma$

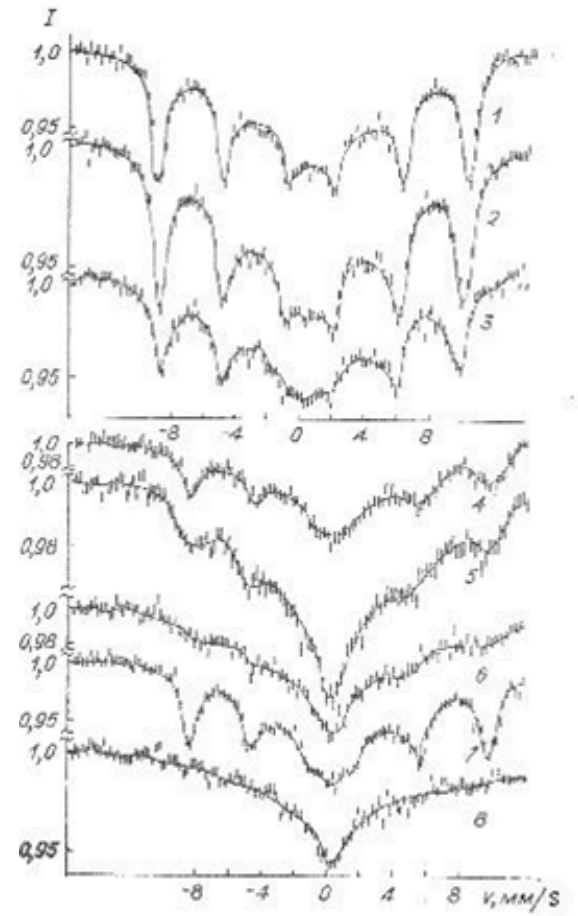

Fig.2. Mossbauer spectra of wetted EDE-10P polymer containing $\mathrm{Fe}(\mathrm{III})$ after treated with $\mathrm{NaF}$ solution at 80 (1), 116 (2), 150 (3), 172 (4), 209 (5) and $230 \mathrm{~K}(6)$, and a dry sample in air at $80(7)$ and $300 \mathrm{~K}(8)$. and $\mathrm{f}^{\prime}$ as deduced from experimental spectra.

The low temperature Mossbauer spectra of EDE$10 \mathrm{P}$ sample, that retained iron ions from the $\mathrm{Fe}_{2}\left(\mathrm{SO}_{4}\right)_{3}$ solution after treating with $\mathrm{NaF}$ solution, are characterized by appearance of the magnetic hyperfine structure (MHS) [33]. In the EDE-10P polymer phase the paramagnetic $\mathrm{Fe}^{3+}$ ions are in spin blocking state and in this case the magnetic hyperfine structure is evidenced through a slow relaxation of the electronic spin [35]. With increasing temperature T> $80 \mathrm{~K}$ the electronic spin relaxation time of $\mathrm{Fe}^{3+}$ ions in the wetted EDE -10P polymer phase is diminished and from $\mathrm{T}>$ $230 \mathrm{~K}$ the MHS lines merge into a singlet component (Fig. 2 ) reflecting a very fast and complete relaxation of spins.

The ground term $\left({ }^{6} \mathrm{~S}\right)$ of $\mathrm{Fe}^{3+}$ ions in the polymer processed by solution of $\mathrm{NaF}$ is spitted due to ligands crystalline field into three Kramers doublets $\mathrm{S}= \pm 5 / 2, \pm$ $3 / 2$ and $\pm 1 / 2$, which all are populated by electrons. With increasing temperature the spectral lines of the magnetic hyperfine structure (MHS) sextets became larger, but do not change sensibly their position. Since the Fe content in the EDE-10P polymer phase is small, around $2 \%$, and taking into account the results from [16], it may be as above inferred that the evolution of MHS is characterized by a spin - lattice relaxation type.

Fluor anions completely destroy the Fe(III) compounds with groups-ligands of EDE-10P polymer as derived from Mossbauer spectra (at $\mathrm{T}>230 \mathrm{~K}, \mathrm{f}^{\prime}=0$ for damp sample) [34]. For air dry sample of EDE-10P the relaxation time remains quite high. In this case the formed $\mathrm{Fe}(\mathrm{III})$ compounds are located near the functional groups of the polymer. The values of $\delta_{\mathrm{Na}+}=0.70 \pm 0.15 \mathrm{~mm} / \mathrm{s}$ and $\mathrm{H}_{\mathrm{ef}}=580 \pm 10 \mathrm{kOe}\left(\mathrm{H}_{\mathrm{ef}}\right.$ - effective magnetic field intensity on $\mathrm{Fe}^{3+}$ nucleus) indicate that iron compounds with $\mathrm{F}$-anions in the polymer phase contain $\mathrm{Fe}^{3+}$ ions in the high-spin state and hexagonal coordination environment according to the data from [36]. Furthermore, the symmetrical ESR spectrum, with the relatively narrow spectral line $(\Delta \mathrm{H}=104 \mathrm{Oe}$ at semi height) and $\mathrm{g}=2.005$ (77 $\mathrm{K})$ [33], allows, according to [37], to consider that in the EDE 10P polymer phase which contains Fe (III) when processing it by the NaF solution then the $\left[\mathrm{FeF}_{4}\left(\mathrm{H}_{2} \mathrm{O}\right)_{2}\right]^{-}$ions are formed and subsequently are retained by the polymer as a result of Coulomb interactions.

\section{The iron ions state in outspent ion exchangers during water treatment}

Using Mossbauer spectroscopy it has been investigated the ion exchangers KU-2 and AN-31 which were depleted in water treatment in the first step and the AV-17, Varion - AD - in the second step of the Moldavian thermoelectric station [37.38 ]. Since the iron content in these polymers was relatively small ( 0.5 to $2.75 \mathrm{mg} / \mathrm{g})$ the polymer samples were thermally treated in air at different temperatures up to $550{ }^{\circ} \mathrm{C}$. The Mossbauer spectra of AV-17 sample are shown in Fig. 3, and the parameters of Mossbauer spectra of AV-17 and Varion-AD samples in the Table 2. 
The MS parameters show that in the phase of mentioned-up polymers iron is in the ultrafine particles of $\beta$-FeOOH, which during the thermal processing of polymer are transformed in $\gamma$ - then $\alpha-\mathrm{Fe}_{2} \mathrm{O}_{3}$. According to [39] the transformation of iron(III) oxohydroxide to $\alpha$ - $\mathrm{Fe}_{2} \mathrm{O}_{3}$ passes across the formation step of a paramagnetic phase $\mathrm{x}-\mathrm{Fe}_{2} \mathrm{O}_{3}$ particles with $d_{c}=80 \pm 20 \AA\left(d_{c}-\right.$ is critical diameter $)$. When the particles have $\mathrm{d}>\mathrm{d}_{\mathrm{C}}$ the $\mathrm{x}-\mathrm{Fe}_{2} \mathrm{O}_{3}$ is transformed to $\gamma-\mathrm{Fe}_{2} \mathrm{O}_{3}$, and when the particles become more massive $(\sim 300 \AA)$ - to $\alpha-\mathrm{Fe}_{2} \mathrm{O}_{3}$. With decreasing of particle size of $\mathrm{Fe}(\mathrm{III})$-oxide at $\mathrm{d}$ $<\mathrm{d}_{\mathrm{C}}$, in case of presence of superparamagnetism, outer sextet lines of the Mossbauer spectra became wider but reduced their intensities and are moving inward to the center until a broad relaxing singlet is formed [40]. Since the superparamagnetic state depends not only of particle size but also of temperature. In the case when the particles dimensions are slightly larger than the $d_{C}$ the superparamagnetic state of magnetic ordered particles appears when the temperature is increasing. Such a situation was observed in the MS with increasing temperature from 300-370 K for used-up Varion -AD sample previously thermally treated at $550^{\circ} \mathrm{C}$ (Fig. 4) [37].

Therefore it can be concluded that there are ultrafine particles of $\mathrm{Fe}_{2} \mathrm{O}_{3}$ in the used-up and heat treated at $550^{\circ} \mathrm{C}$ Varion -AD polymer phase as well as there are $\beta-\mathrm{FeOOH}$ ultrafine particles in the exhausted but not heat-treated polymer.

It is known [41], that $\beta-\mathrm{FeOOH}$ is chemically more inert than other $\mathrm{FeOOH}$ allotropic forms, which makes difficult for regeneration of ion exchangers. The chemical stability of $\beta$-FeOOH can be explained not only by its special structure, but also due to the fact that the $\mathrm{Cl}$-ions enter in its composition [41.42]. The investigations [43] have demonstrated that in this case the composition of precipitate consist of " $\beta-\mathrm{FeOOH}+$ $\beta$-FeOOH$(\mathrm{CL})$ " and has the anion exchange properties. The anions with 1 - charge $\left(\mathrm{NO}_{3}^{-}\right)$substitute the $\mathrm{Cl}^{-}$ion from $\beta$-FeOOH easier than anions with larger charge $\left(\mathrm{SO}_{4}{ }^{2-}\right)$. The anion exchange capacity of $\beta-\mathrm{FeOOH}$ depends on $\mathrm{pH}$ and at $\mathrm{pH} 3$ it is a $1 \mathrm{mmol}\left(\mathrm{Cl}^{1-}\right) / \mathrm{g}[44]$.

It is necessary to mention, that after clearing the cause of earlier used-up limit for ion exchangers, the water source alimentation at the Moldavian thermoelectric station was changed.
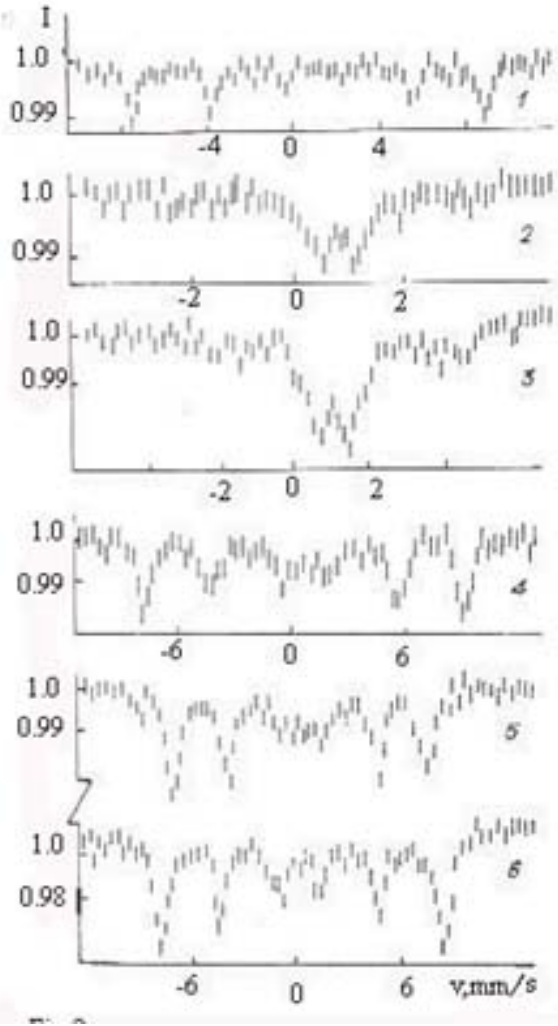

Fig. 3. Mossbauer spectra at $80(1,4)$ and 300 $\mathrm{K}(2,3,5,6)$ of outspent $\mathrm{AV}-17$ sample after thermo processing at $20(1,2), 160(3), 260$ $(4,5)$ şi $550^{\circ} \mathrm{C}(6)$.

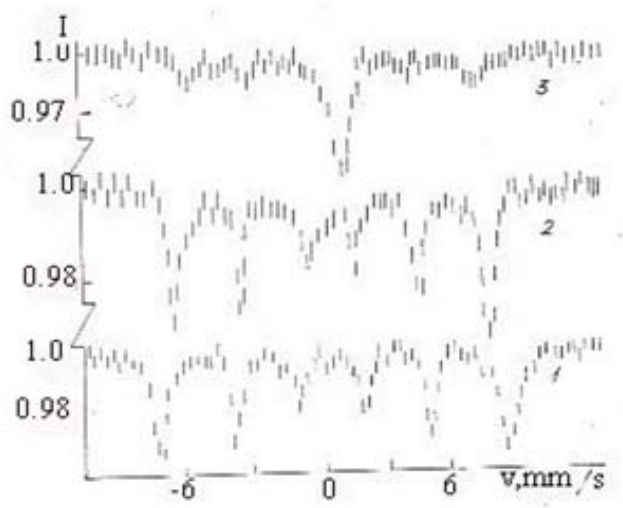

Fig.4. The Mossbauer spectra obtained at 80(1), 300 (2), and $370 \mathrm{~K}(3)$ of exhaustive Varion-AD anionit thermoprocessing at $550^{\circ} \mathrm{C}$. 
The Mossbauer spectra parameters of termo processing anionites at 300 and $80 \mathrm{~K}$ (in brackets).

\begin{tabular}{|c|c|c|c|c|c|}
\hline $\mathrm{t},{ }^{0} \mathrm{C}$ & \multirow{2}{*}{$\begin{array}{r}\delta_{\mathrm{Na}+}, \mathrm{mm} / \mathrm{s} \\
\mathrm{AV}-17\end{array}$} & \multirow[t]{2}{*}{$\mathrm{H}_{\mathrm{ef}}, \mathrm{kOe}$} & $\delta_{\mathrm{Na}+}, \mathrm{mm} / \mathrm{s}$ & & $\mathrm{co}$ \\
\hline & & & \multicolumn{3}{|c|}{ Varion-AD } \\
\hline 20 & $0,62(0,62)$ & $0(492,5)$ & 0,6 & $0(480)$ & $\mathrm{H}$ \\
\hline 160 & $0,74($ & $0(448)$ & 0,63 & $0(486)$ & $\mathrm{OH}$ \\
\hline 260 & 0,63 & $492(518)$ & 0,69 & $477(512)$ & $\mathrm{OOOH}$ \\
\hline 350 & 0,70 & 515 & & 540) & $\gamma-, \alpha-\mathrm{FeOOH}$ \\
\hline 450 & $0,84($ & $508(546)$ & & $497(528)$ & $\mathrm{OH}$ \\
\hline 550 & $0,72(0,78)$ & $517(512)$ & $0,74(0,69)$ & $528(528)$ & $\alpha-\mathrm{FeOOH}$ \\
\hline
\end{tabular}

\section{The iron ions state in the ion reticulate exchangers phase containing strongly basic groups}

The monofunctional anion exchangers containing strongly basic groups $\left(\mathrm{R}_{4} \mathrm{~N}^{+}\right)$, do not containing in their matrix the atoms with negative charge or electron donors. In this case, theoretically, they are not entitled to retain cations from solution in static conditions. But in dynamic conditions, being in $\mathrm{OH}^{-}$form, they can retain the metal cations which are readily hydrolyzed and forming hydroxides [31]. However, surprisingly, it was demonstrated [8.21], that such polymers can retain hydroxocations of $\mathrm{Fe}$ (III) in the static conditions from the sulphate solutions with $\mathrm{pH}=2.0$ at equilibrium. In the same conditions these polymers do not retain hydroxocations of $\mathrm{Fe}(\mathrm{III})$ from the solutions of $\mathrm{FeCl} \mathrm{O}_{3} \mathrm{Fe}\left(\mathrm{NO}_{3}\right)_{3}$. The curve of the $\mathrm{Fe}$ (III)-containing cations sorption from sulphate solutions on anion exchangers AV-17 (containing $\mathrm{R}_{4} \mathrm{~N}^{+}$ group) and Varion-AD (containing $\mathrm{R}_{4} \mathrm{~N}^{+}$and $\mathrm{ROH}$ groups) vs. temperature passes through maximum Fig. 5) [45].

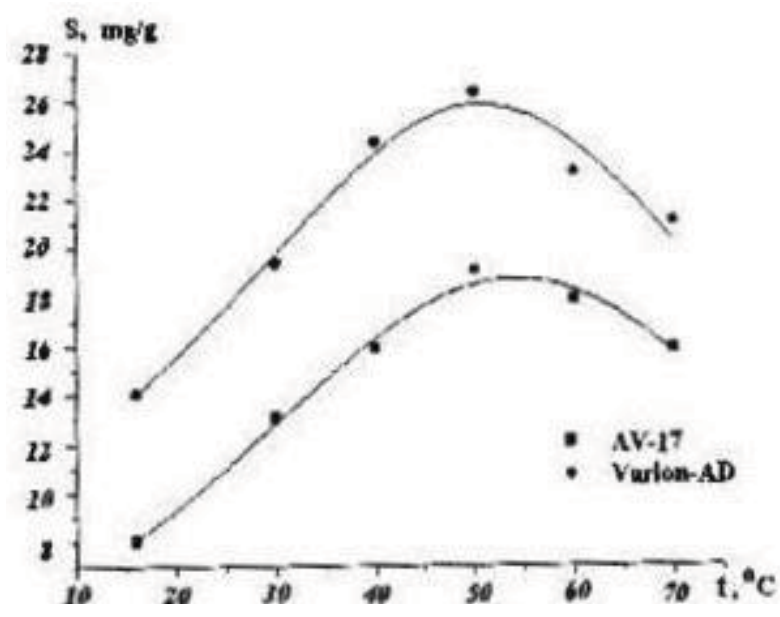

Fig. 5. The temperature dependence of Fe(III) sorbtion by AV-17 and Varion - AD polymers.

Anyhow, it can be affirmed that the retention of cations by anion exchangers containing strongly basic groups is a chemical process and not a physical one. Sorption of Fe(III) cations by strongly basic polymers takes place in a medium (polymer phase) with relatively high concentration of $\mathrm{SO}_{4}{ }^{2}$-anions, and in principle could form anionic complexes inside the polymer phase, which will be electrostatically retained. But it is well known that the ion exchange is the process which almost does not depend on temperature.

As it is shown in [8] in the AV-17 polymer phase which was in contact with $\mathrm{Fe}_{2}\left(\mathrm{SO}_{4}\right)_{3}$ solution (pH 1.7 and concentration from 0.03 to $0.06 \mathrm{~N}$ ), there is a solid iron(III) compound (doublet in the Mossbauer spectrum) and $\left[\mathrm{Fe}\left(\mathrm{H}_{2} \mathrm{O}\right)\right]^{3+},\left[\mathrm{FeOH}\left(\mathrm{H}_{2} \mathrm{O}\right)_{5}\right]^{2+}$ (sextets in the spectrum). The dimmer ions of oxo-or hydroxocomplexes of Fe (III) ions in polymer phase were not detected. There is only one type of solid Fe (III) compound in the polymer phase after contacting with $\mathrm{Fe}_{2}\left(\mathrm{SO}_{4}\right)_{3}$ solution at $\mathrm{pH} 1.85-2.00$. The parameters of Mossbauer spectra of these compounds $\left(\Delta \mathrm{E}_{\mathrm{Q}}=1 \mathrm{~mm} / \mathrm{s}\right)$ are close to corresponding parameters which are characteristic to Jarosite mineral: $\mathrm{A}\left[\mathrm{Fe}_{3}(\mathrm{OH})_{6}\left(\mathrm{SO}_{4}\right)_{2}\right]$, where $\mathrm{A}$ may be $=$ $\mathrm{Na}^{+}, \mathrm{K}^{+}, \mathrm{H}_{3} \mathrm{O}^{+}, \mathrm{NH}_{4}^{+}$and other cations [46.47], or hydrated compound $\mathrm{FeOHSO}_{4}$ [46-48]. The compounds like Jarosite mineral type are obtained during hydrolytic precipitation of $\mathrm{Fe}^{3+}$ ions in the presence of $\mathrm{SO}_{4}^{2-}$ anions [48.50].

The Jarosite mineral is not notably stable in the normal atmospheric environment, partially transforming in to $\mathrm{Fe}(\mathrm{OH})_{3}$ [50]. The $\mathrm{Fe}_{2}\left(\mathrm{SO}_{4}\right)_{3}$ solution interacts with freshly precipitated $\mathrm{Fe}(\mathrm{OH})_{3}$ giving rise, in dependence of 
temperature, to soluble or insoluble $\mathrm{FeOHSO}_{4}$ [51.52]. The Jarosite mineral type compounds are stable up to about $230^{\circ} \mathrm{C}$ on heating in air, and at $\mathrm{T}>230^{\circ} \mathrm{C}$ one of the thermodecomposing products is $\mathrm{FeOHSO}_{4}$ [53]. Following the thermal dehydration of $\mathrm{FeOHSO}_{4}$, the $\Delta \mathrm{E}_{\mathrm{Q}}$ value grows considerably. Boiling in water the iron(III) compounds such as Jarosite are transformed into $\alpha$-FeOOH in superparamagnetic state [47].

Under thermal treatment in air up to $200^{\circ} \mathrm{C}$ of $\mathrm{Fe}$ (III) Jarosite mineral type compounds in the AV-17 polymer phase the red-ox processes take place and the Fe (II) compounds as well as stable libber radicals are formed [54]. Mossbauer spectra parameters of AV-17 sample containing Jarosite do not change essential when the sample was heated up to $180^{\circ} \mathrm{C}$. So in the $\mathrm{AV}-17$ polymer phase there is not formed $\mathrm{FeOHSO}_{4}$ when it is in contact with solution of $\mathrm{Fe}_{2}\left(\mathrm{SO}_{4}\right)_{3}$. Furthermore, when boiling in aqueous medium the Jarosite from polymer phase is converted to ultrafine particles of $\mathrm{FeOOH}$ showing superparamagnetic state.

During a few cycles "sorption of Fe (III) then boiling in water", one part of the magnetic particles become relatively large and magnetically ordered, while another part remains in superparamagnetic state due to location in narrow pores of the polymer [55]. In the solution of $\mathrm{Fe}_{2}\left(\mathrm{SO}_{4}\right)_{3}$ with pH 2.0 there are $\left[\mathrm{Fe}\left(\mathrm{H}_{2} \mathrm{O}\right)_{6}\right]^{3+},\left[\mathrm{FeOH}\left(\mathrm{H}_{2} \mathrm{O}\right)_{5}\right]^{2+}$ and $\left[\mathrm{Fe}_{2}(\mathrm{OH})_{2}\left(\mathrm{H}_{2} \mathrm{O}\right)_{8}\right]^{4+}$ ions [55.56]. The dimeric hydroxocomplexes were not detected in the polymer phase via contacting with $\mathrm{Fe}_{2}\left(\mathrm{SO}_{4}\right)_{3}$ solution. These complexes are hardly changed to organize in new structural units [57]. The $\left[\mathrm{Fe}\left(\mathrm{H}_{2} \mathrm{O}\right)_{6}\right]^{3+}$ ions does also not directly participate in the formation of compounds like Jarosite mineral. So in the polymer phase the $\left[\mathrm{FeOH}\left(\mathrm{H}_{2} \mathrm{O}\right)_{5}\right]^{2+}$ ions participate to the formation of compounds of Jarosite mineral type:

$$
\begin{aligned}
& \mathrm{R}_{4} \mathrm{~N}^{+}+2 \mathrm{SO}_{4}{ }^{2-}+3\left[\mathrm{FeOH}\left(\mathrm{H}_{2} \mathrm{O}\right)_{5}\right]^{2+}+3 \mathrm{OH}^{-} \leftrightarrow \mathrm{R}_{4} \mathrm{~N}\left[\mathrm{Fe}_{3}(\mathrm{OH})_{6}\left(\mathrm{SO}_{4}\right)_{2}\right]+15 \mathrm{H}_{2} \mathrm{O} \\
& \mathrm{H}_{3} \mathrm{O}^{+}+2 \mathrm{SO}_{4}^{2-}+3\left[\mathrm{FeOH}\left(\mathrm{H}_{2} \mathrm{O}\right)\right]^{2+}+3 \mathrm{OH}^{-}=\mathrm{H}_{3} \mathrm{O}\left[\mathrm{Fe}_{3}(\mathrm{OH})_{6}\left(\mathrm{SO}_{4}\right)_{2}\right]+15 \mathrm{H}_{2} \mathrm{O}
\end{aligned}
$$

In boiling aqueous solution the iron compounds such as mineral Jarosite decompose according the scheme (6):

$$
2 \mathrm{R}_{4} \mathrm{~N}\left[\mathrm{Fe}_{3}(\mathrm{OH})_{6}\left(\mathrm{SO}_{4}\right)_{2}\right]=\left(\mathrm{R}_{4} \mathrm{~N}\right)_{2} \mathrm{SO}_{4}+6 \beta-\mathrm{FeOOH}+3 \mathrm{SO}_{4}^{2-}+6 \mathrm{H}^{+}
$$

Jarosite mineral formation can take place only in the presence of water. When this mineral was found on Mars it was deduced that water is present there too and latter confirmed.

The Jarosite mineral type compounds are formed as layers of 3 or 6 octahedral cycles [49]. The OH-groups are located in the equatorial plane, forming a bridge between metal ions and $\mathrm{SO}_{4}{ }^{2}$ groups are located in axial position, each coordinating 3 metal ions of 3 octahedrons.

The Jarosite mineral type compounds presence in polymers phase changes essentially their physical-chemical properties. The $\mathrm{R}_{4} \mathrm{~N}^{+}$and $\mathrm{H}_{3} \mathrm{O}^{+}$ions from compounds can be exchanged with different cations but at the same time the anions $\mathrm{SO}_{4}{ }^{2-}$ connect with different other anions or molecules able to form coordination bonds with the central metal ions.

The alunit type mineral $\mathrm{K}\left[\mathrm{Al}_{3}(\mathrm{OH})_{6}\left(\mathrm{SO}_{4}\right)_{2}\right]$ is izostructural with Jarosite mineral. So, at contacting with $\mathrm{Al}_{2}\left(\mathrm{SO}_{4}\right)_{3}$ solution in the phase of strongly basic anion exchangers it may be formed compounds such alunit [13 ]. Moreover, in the analogical conditions it may be formed compounds like Jarosite mineral type containing other cations species which differ of $\mathrm{Fe} 3+$ or $\mathrm{Al}^{3+}[12]$.

The reticulated ionic polymers containing in their matrix not only strongly basic groups, but other chemically active functional groups such as - $\mathrm{COOH}$,-CN etc, also may retain metal cations $\left(\mathrm{M}^{3+}\right)$ from the solutions of sulfate as a result of training compounds like Jarosite mineral, as well as function of coordination with electron donor atoms of the polymer [58].

\section{Conclusions}

To understand more deeply the formation of metal compounds in chemical active reticulate polymer phase and the processes connected with utilization in different areas of these composites uploaded with metallic compounds polymers it is imperiously required their investigation using various complementary physical methods, including Mossbauer spectroscopy in special.

\section{Acknowledgements}

The authors gratefully thank Silvia Melnic and Dumitru Sirbu for assistance provided in preparation of this manuscript.

\section{References}

[1]. Visotskii, S.P.; Peaterikov, V.V.; Kopilova, O.N. Teploenergetika. 1982,.№7, 58-59. (rus.)

[2]. Method of cleaning of sulfonated from iron oxides / AM Dedyukhin / Bul.Izobr.1979,. № 8, 26. (rus.) 
[3]. Foshko. Increased reliability and efficiency water chemical conditions, ways to simplify the technological schemes and lowering the cost of water treatment at the units S.K.D. and large TETS S.D.V; Leningrad: CKTI II Polzunova. 1973, 128-134 (rus).

[4]. Saldadze, K.M.; Pashkov, A.B.; Titov V.S High-molecular-weit ion exchange.materials, Goskhimizdat: Moscow, 1960. 356 (rus.)

[5]. Nazarova, R.S.; Sandar, A.A.; Andreev, M.B.; Kovalev, M.P. Plastics. 1974, № 4, 72- (rus)

[6]. Gutsanu V.L. Doct.Habilitat. Thesis, State University of Moldova. Chisinau, 1993 (rus.)

[7]. Saldadze, K.M.; Kopylova-Valova, V.D. Complex-forming ion exchangers (kompleksities). Chemistry: Moscow, 1980. 336. (rus.)

[8]. Gutsanu V.L.; Turta, C.; Gafiiciuc, V.A.; Shofranski, V.N. Russ. J. Phys. Chem. 1988, T.62. pp.2515-2422. (rus.)

[9]. Gutsanu V.L. Chemistry and Technology of Water.1990, T.12. №12 pp. 1074-1097. (rus.)

[10]. Copylova, V.D.; Astanina, A.H. Ion exchanger complexes in catalysis. Chemistry: Moscow. 1987 . 191 (rus.)

[11]. Guțanu V., Druță R. Procedeu de obținere a ioniților modificați. Brevet de invenție, MD 810. // BOPI, 1997,nr.8, p.24-25

[12]. Guțanu V., Druța R. Procedeu de moificare cu Cr(III) a polimerilor ionogeni reticulați ce conțin grupe R4N+ . Brevet de invenție, MD 1027. // BOPI,1998. nr.9. p.23

[13]. Guțanu V., Druța R. Obținerea sorbenților selectivi pentru sorbția coloranților alimentari din soluții // Materialele I simposion internațoinal "Biochimie şi biotehnologii în îndustria alimentara ” .Chişinău. Tehnica -Info.2002. p.210-215

[14]. Guțanu V., Cojocaru L. Procedeu de obținere a sorbentului selectiv care conține compuşi de Bi (III) . Brevet de invenţie, 32.95 MD . // BOPI, 2007,nr.4, p.42-43

[15]. Suzdalev, I.P. Gamma-rezonance spectroscopy of proteines and model compounds. Nauca: Moscow. 1988.262 pp. (rus.)

[16]. Suzdalev, I.P.; Afanasiev, A.N.; Placinda, A.S.; Golidanskii, V.I. Journ.Exper. and Theor. Physics. $1968,55$. 1752-1765 (rus).

[17]. Laskorin, B.N.; Ligvinenko, I.A.; Fedorova, L.A.; Ashurkova, C.B. Journ. Anal. chemistry. 1969.T.42. № 6, s.1320-1325 (rus.)

[18]. Suzdalev, I.P.; Plachinda, A.S.; Makarov, E.F.; Dolgopolova, V.A. Russ. J. Phys. Chem. 1967, V.41, № 11. 28312837 (rus.)

[19]. Gutsanu, .VL.; Turte, K.I.; Muntean, S.A. et al Russ. J. Phys. Chem 1990, 64, № 2, 479-487 (rus.)

[20]. Dzevitsky B.E., Zviadadze GN, Margulis, VB et al. Russ. Coord. Chem. 1977,3, № 7, 643 - 647 (rus.)

[21]. Gutsanu, V.L.; Gafiychuk, V.A. Russ. J. Phys. Chem 1986, 60,1824-1826. (rus.)

[22]. Gutsanu, .VL.; Muntean, S.A.; Turte, K.I Bull. AN MSSR, Ser. biol. and chem. science.1980, N:2, 73-79(rus.).

[23]. Gutsanu, .V.L.; Dogaru G.N. Russ. J. Phys. Chem. 1985, 54, №8, 2098-2101 (rus.).

[24]. Gutsanu, .V.L.; Turte K.I.; Stukan, R.A.; Gafiychuk, V.A. Russ. J. Phys. Chem. 1985, 59, № 3, $693-696$ (rus.)

[25]. Safin R.Sh.; Gutsanu, .V.L.; Vishnevskaya G.P. Russ. J. Phys. Chem. 1987, 61, №8, 2134 - 2138(rus.).

[26]. Lurie, A,L. Sorbents and chromatographic carriers. Nauka: Moscow. 1972. 320 pp. (rus.)

[27]. Turte KI, Gutsanu, .V.L.; Bobkova, SA etc. The study of complexation of iron ions on the anion exchanger AN2FN / . Izv.Acad.Nauk MSSR. Ser. biol. and chem. science.1980, 4, 54-60 (rus.).

[28]. Krestov, G.A.; Klopov, V.I.; Patsatsia, K.M. Journ. Strukt. Chemistry .1969, 10, № 3,417-422 (rus).

[29]. Buslaeva, M.N.; Samoilov, O.Y. Journ. Strukt. Chemistry. 1963,4, № 4, 502-505 (rus).

[30]. Gutsanu, .V.L.; Gafiychuk, V.A. Chemistry and Technology of Water. 1989, T.11, № 7, 584-588 (rus). .

[31]. Gutsanu, .V.L.; Stukan, R.A., Turte, K.I., Gaftychuk, V.A. Russ. J. Phys. Chem. 1986, T.60, C.936-940 (rus).

[32]. Gol'danskii, V.I.; Makarov, E.F.; Stukan, R.A. Proc. AS USSR. 1964, T.156, № 2, C.400-403 (rus).

[33]. Gutsanu, .V.L.; Gafiychuk, V.A. Russ. J. Phys. Chem. 1990.64, № 2, 488-494 (rus).

[34]. Astanina, A.N.; Fung, Chi Chi; Rudenko, A.P., etc. Russ. J. Phys. Chem. 1983, 57, № 6, 1397-1399 (rus).

[35]. Chemical Applications of the Messbauer Spectroscopy, Ed. VI Gol'danskii, R.Herber. Mir: Moscow.1970 (rus).

[36]. Edwards, R.P., Johnson, C.E. J.Chem. Phys.1968, v.49, №1, p.211-216.

[37]. Gutsanu, .V.L.; Turte, K.I.; Labunskaya N.Y. Russ. J. Phys. Chem. 1987, 61, № 1, 170-174 (rus).

[38]. Gutsanu, .V.L.; Turte, KI, Labunskaya N.Y. Chemistry and techn. of water. 1987, T.9, № 6, 514-517(rus).

[39]. Krupyansky, Y.F.; Suzdalev, I.P. Journ.exper. and theor. phys. 1973, 65, № 4, 1715-1725 (rus).

[40]. Suzdalev, I.P. Solid State Physics. 1970, 14, № 4, 988-990 (rus).

[41]. Wever, I.E.; May, L.A., Bull. AS Lat. SSR. Ser. Chem.,1979, 2, 147-153 (rus).

[42]. Borggard, O.K. Acta Chem. Scand . 1988, A37, №2, 169-171

[43]. Gutsanu, .V.L.; Labunskaya, N.Y. Russ. J. Phys. Chem.. 1986, 60, №12, 3113-3116(rus).

[44]. Paterson Russeli, Rahman Habibar. J. Colloid. Interface Sci. 1983, 94, №1, 60-69. 
[45]. Gutsanu, V., Raisa Drutsa, Rusu V. Reactive and Funct. Polym., 2001, 46, 203-211

[46]. Hrynkiewicz, A.Z., Kubisz, I., Kulgawczuk, D.S. J. Inorg. Nucl. Chem. 1965, 27, №12, 2513-2517.

[47]. Matashige Ohyabu, Iusuke Ujihira .J. Inorg.. Nucl. Chem. 1981, 43, 1948 -1949.

[48]. Morais, P.S.; Neto, K.S. Polyhedron. 1983, 2, № 9, 875-880.

[49]. Archipenko, D .K, Deviatkina, ET, Palchik, NA, Crystallochemical particularities of synthetic jarosites. Novosibirsk, Nauka 1987.

[50]. Betekhtin, AG, Mineralogy. Gos. Acad. Geolog. Litr.: Moscow. 1950. 5-73.(rus.)

[51]. Milner, A.; Zapolsky, A.K.; Ryzhuk, N.P.; Jour.n.Appl. Chem. 1986, 59, 499-504.(rus.)

[52]. Zapolsky, A.K.; Milner, A.; Ryzhuk, N.P. et al. Chem. and Techn. of water.1985, 7, № 6,

[53]. 70-73 (rus).

[54]. Margulis, E.V.; Savchenko, L.A.; Shokarev, M.M.; et al. Russ. J. Inorg. Chem. 1973, 18, № 5, $1263-1269$ (rus).

[55]. Gutsanu, V.; Gafiichuk, V.; Shofransky, V.; Turta, C. J. Appl. Polym. Sci., Vol. 99, 59-64.(rus.)

[56]. Fishtik I.F.; Vataman, I.I. Thermodynamics of Metal Ion Hydrolysis. Shtiintsa: Kishinev. 1988) [in Russian].

[57]. Yakubov, J.M.; Ismailov, M.A.; Offengenden E.Y.; Ibragimov, D.C. Hydroxyl complexation in redox systems. Taj. State Univ:: Dushanbe. Issue 3, 5-36 (rus).

[58]. Belozersky, GN, Baikov, M., Boldyrev, VV, et al. Kinetics and Catalysis 1974, 15, № 4, 929-934 (rus).

[59]. Gutsanu, V.; Luca, C.; Neagu, V.; Shofransky, V.; Turta, C. Reactive and Funct. Polym.1999, 40, 123-128. 